CT\&F - Ciencia, Tecnología y Futuro - Vol. 4 Num. 3 Jun. 2011

\title{
DENSE SUSPENSIONS FORMULATIONS FOR UPGRADING PROCESSES IN HEAVY AND EXTRA HEAVY CRUDE OIL
}

\author{
Lilia Rodríguez ${ }^{1^{*}}$ and Geoffrey Viviescas ${ }^{2^{*}}$ \\ 'Ecopetrol S.A. - Instituto Colombiano del Petróleo - (ICP), A.A. 4185 Bucaramanga, Santander, Colombia \\ ${ }^{2}$ CTP Ltda. - Piedecuesta, Santander, Colombia \\ e-mail: lilia.rodriguez@ecopetrol.com.co geoffrey.viviescas@ecopetrol.com.co
}

(Received Mar. 08, 2011 ; Accepted May 25, 2011)

\section{ABSTRACT}

T

The present work involved the formulation of solid-liquid suspensions of by-products of heavy and extra heavy crude oil process upgrades, coke and asphaltenes from Delayed coking and Deasphalting processes. This was done by controlling rheological properties and following specifications for pipeline transmission, similar to those of liquid hydrocarbons. The formulated products guarantee the possibility of moving the by products in a fluidized way, minimizing storage, handling, environmental and operational costs in transportation, and providing an attractive alternative as non conventional fuel.

Regarding the formulation of suspensions, it was necessary to establish the effect of formation components such as: surfactants, stabilizers, as well as the type, amount of solids and particle size ratio on the flow properties of the resulting product.

The parameters analyzed for rheological properties of pipeline transport were viscosity, particle size distribution, static and dynamic stability.

Laboratory tests were performed in high precision rheometers -TA Instruments RX1500 and Haake RS600- and Mastersizer 2000 particle size analyzer. At pilot scale, we used a closed loop to verify flow parameters, including normal and critical transport scenarios: Sudden shutdowns and extended ones of up to 72 hours, with subsequent pumping re-starts.

Tests performed at the lab and the pilot plant showed better rheological properties in the formulations with bimodal particle size distribution. This allowed higher loads of solid, up to $52 \%$, and an improved mobility, reflected as lower viscosity. A non-Newtonian rheological behavior became evident, characterized by yield stress to ensure pumpability after prolonged inactivity. The pressure drops and calculation of apparent viscosity obtained in the pilot plant were compared and verified with lab results, showing reproducibility.

Keywords: Rheological behavior, Petroleum coke, Asphaltenes, Solid transport, Suspensions, Heavy oil, Upgrading.

Citation: Rodríguez, L. \& Viviescas, G. (2011). Dense suspensions formulations for upgrading processes in heavy and extra heavy crude oil. CT\&F - Ciencia, Tecnología y Futuro, 4 (3), 61-72.

${ }^{*}$ To whom correspondence may be addressed 


\section{RESUMEN}

$\int^{e}$ extron e formularon suspensiones sólido-liquido de subproductos de procesos de mejoramiento de crudos pesados y extra-pesados, coque y asfaltenos de procesos de Delayed coking y Desasfaltado respectivamente, a partir del control de propiedades reológicas, buscando especificaciones de transporte por tubería, similares a las que cumple un hidrocarburo liquido. Los productos formulados garantizan la posibilidad de transportar de manera fluidizada los subproductos minimizando problemas de almacenamiento, manipulación, costos ambientales y operativos durante su transporte y ofrecen una alternativa energética atractiva como combustible no convencional.

Para la formulación de las suspensiones fue necesario establecer el efecto de los componentes de formación tales como agentes dispersantes, estabilizantes, así como el tipo, cantidad de sólidos y relación de granulometrías, en las propiedades de flujo del producto resultante. Los parámetros analizados para obtener las propiedades reológicas de transporte por tubería fueron viscosidad, distribución del tamaño de partícula, estabilidad estática y estabilidad dinámica.

Las pruebas de laboratorio se realizaron en reómetros de alta precisión; TA Instrumentes RX1500 y Haake RS600; analizador de tamaño de partícula Mastersizer 2000. A escala piloto, se empleó un circuito cerrado donde se verificaron los parámetros de flujo, incluyendo escenarios de transporte normales y críticos: Paradas súbitas y prolongadas de hasta 72 horas con posteriores re-inicios de bombeo.

Las pruebas de laboratorio y planta piloto mostraron mejores características reológicas para las formulaciones con distribución de tamaño de partícula bimodal; permitiendo mayor carga de sólido, hasta $52 \%$ y alta movilidad, reflejada como menor viscosidad. Se presentó comportamiento reológico no newtoniano con esfuerzos de cedencia que aseguran bombeabilidad tras una parada prolongada. Las caídas de presión y el cálculo de viscosidad aparente obtenidos en planta piloto se compararon y verificaron con los resultados obtenidos en laboratorio, mostrando reproducibilidad.

Palabras claves: Comportamiento reológico, Coque del petróleo, Asfaltenos, Transporte de sólidos, Suspensiones, Crudos pesados, Upgrading.

\section{RESUMO}

$\mathrm{F}$ oram formuladas suspensões sólido-líquido de subprodutos de processos de melhoramento de crus pesados e extra pesados, coque e asfaltenos de processos de Delayed coking e Desasfaltado respectivamente, a partir do controle de propriedades reológicas, buscando especificações de transporte por tubulação, similares às que cumpre um hidrocarboneto líquido. Os produtos formulados garantem a possibilidade de transportar de maneira fluidizada os subprodutos minimizando problemas de armazenamento, manipulação, custos ambientais e operativos durante seu transporte e oferecem uma alternativa energética atrativa como combustível não convencional.

Para a formulação das suspensões foi necessário estabelecer o efeito dos componentes de formação tais como agentes dispersantes, estabilizantes, assim como o tipo, quantidade de sólidos e relação de granulometrias, nas propriedades de fluxo do produto resultante. Os parâmetros analisados para obter as propriedades reológicas de transporte por tubulação foram viscosidade, distribuição do tamanho de partícula, estabilidade estática e estabilidade dinâmica.

As provas de laboratório foram realizadas em reômetros de alta precisão; TA Instrumentes RX1500 e Haake RS600; analisador de tamanho de partícula Mastersizer 2000. À escala piloto, foi empregado um circuito fechado onde foram verificados os parâmetros de fluxo, incluindo cenários de transporte normais e críticos: paradas súbitas e prolongadas de até 72 horas com posteriores re-inícios de bombeio.

As provas de laboratório e fábrica piloto mostraram melhores características reológicas para as formulações com distribuição de tamanho de partícula bimodal, permitindo maior carga de sólido, até $52 \%$ e alta mobilidade, refletida como menor viscosidade. Apresentou comportamento reológico não newtoniano com esforços de cedência que garantem bombeabilidade depois de uma parada prolongada. As quedas de pressão e o cálculo de viscosidade aparente obtidos em fábrica piloto foram comparados e verificados com os resultados obtidos em laboratório, mostrando reproducibilidade.

Palavras chaves: Comportamento reológico, Coque do petróleo, Asfaltenos, Transporte de sólidos, Suspensões, Crus pesados, Upgrading. 


\section{INTRODUCTION}

Due to the growing development and implementation of improvement processes (upgrading) of heavy and extra heavy crude, significant volumes of byproducts of difficult handling are generated. These include asphaltenes and petroleum coke (Murray, Elliott \& McCaffrey, 2005). An example of the aforementioned is the BP Carson Refinery in Long Beach, one of California's biggest refineries, with a capacity of $270000 \mathrm{bpd}$ and a production of 1000 tons of petroleum coke per day. Another one is "El Segundo de Chevron" Refinery in California, with a capacity of $280000 \mathrm{bpd}$ and a production of 3600 tons / day of petroleum coke, whose energy and economic value make it more appealing to be marketed as non-conventional fuel. (Wang, Anthony \& Abanades, 2004). Handling large volumes of particulate solid material demands important technical logistics, due to the volatility of this material during storage and transportation stages. Environmental problems are also generated, such as possible contamination of air, water and soil. The technology of coal-water suspensions (CWS) is considered as one of the most useful technologies for transportation and improvement of clean coal (Liu, Zhao, Zhou, Cheng \& Zhang, 2009).

These reasons encourage the search for alternatives of safe transport, which should also be environmentally friendly and commercially appealing. Making the pipeline transport of solids viable, by means of low viscosity suspensions, is part of a strategy to ensure operations with an integral application of new technologies on an industrial scale. (Chen, Duan, Liu \& Zhao, 2010). This is a higher value-added option, since it allows evacuating by-product volumes generated on site, as well as minimizing the environmental risk and obtaining a fluid and homogeneous fuel placed at the end of the tube (Grosso, Suárez \& Leal. 1996). This fuel can be used either for direct burning or for later gasification processes. The suspensions were made in order to maximize the concentration of solids in the continuous or liquid phase, increasing its packaging capacity through the selection of the best grading and the optimization of additive concentration -both surfactants and stabilizers- (Boylu, Ateşok \& Dinçer, 2005). Guaranteeing milling conditions becomes a relevant factor to achieve appropriate distribution of particle sizes. This is done by maintaining a balance between increased availability of solid material in the continuous phase without affecting the rheological behavior (Ateşok, Dinçer, Ozer \& Mutevellioglu, 2005). As the load from solid to liquid increases, the fluid presents a more complex behavior. Ideally, the suspensions formulated adjust their variables within the Law of Stokes parameters. By doing this, they achieve static and dynamic stability, as well as flow conditions to ensure the mobility required for pipeline transport. Combined variables result in a formulation that leads to good rheological behavior and the ability of being transported through pipes, guaranteeing all operational novelties. (Hicyilmaz, Ozün \& Altun, 2006).

Determination of suspensions viscosity -and their rheological behavior- is the key to perform a correct prediction of pressure drops in a pipeline transport system. This process optimizes the design of pumping systems and minimizes energy consumption.

\section{THEORETICAL FRAMEWORK}

The apparent viscosity of solid suspensions can be reduced to a minimum by optimizing the size distribution of particles (Boylu, Dinçer \& Ateşok, 2004). Solid particles, which due to their size distribution exhibit a high packed density, have a more compact structure. As a result, fluids forming the suspension cannot easily enter empty spaces. Even if the fluid enters, these spaces cannot move, flow or move freely in unoccupied ones. Therefore, the rise of internal friction during the movement results in high resistance, causing an increased viscosity. The particles with sizes exhibiting a low packed density have more empty spaces, low viscosity and high fluidity (Ateşok et al., 2005).

Optimizing the granulometric selection is important to obtain the highest concentration of solids at a lower viscosity. This balance, between stability and viscosity, can be achieved through the use of chemical additives, which improve the properties in the continuous phase by minimizing the precipitation of solids and improving mobility. It has been determined that the diameter of the particles used in the preparation of coal-water suspen- 
sion should be a maximum of 250 microns for slurry type (Allen, Rennie \& Welbourne, 1985). However, due to problems associated to sedimentation, and the limitations of particles size during atomization in the combustion processes of slurries, it is not possible to deal with particle sizes above 100 microns. Usually, about $70 \%$ to $80 \%$ of the particles must have a diameter of less than 74 microns and an average particle diameter between 20 and 30 microns (Kefa, Guoquang \& Mingjiang, 1985).

Depending on the application and the requirements of stability and fluidity, the volumetric concentration of solids is usually between $30-70 \%$.

\section{EXPERIMENTAL DEVELOPMENT}

\section{Samples}

The petroleum coke used in experiments was obtained from the Delayed Coking Pilot Plant designed and built by Ecopetrol S.A.-ICP (Picón \& Mahecha, 2001). The asphaltene was produced in the Deasphalting Pilot Plant designed and built by Ecopetrol S.A.-ICP (Grosso et al., 2003). The stabilizing additives used were Galactasol, Bermocol, carboxymethyl cellulose, carboxyethyl cellulose, Celosize and AE. These are substances that, when added to a mixture, increase their viscosity without substantially modifying their other properties. They are often based on polysaccharides of natural origin. As surfactants, we used Ethomid HP60 and Ethomid HT23, ethoxylated amides in a variety of applications to provide dispersibility, and an Anionic Surfactant called $\mathrm{AD}$, a product made by Ecopetrol S.A.-ICP.

The particle size of the byproducts was reduced to less than 600 microns in a ball mill. In addition, we performed a granulometric selection by means of a sieving process. Physical features of the sample are shown in Table 1.

Asphaltenes and petroleum coke were screened through the grain selection shown in Table 2 .

These granulometries were mixed in different concentrations in order to obtain a size distribution that maximizes packing and minimizes sedimentation rate and viscosity. Figure 1 shows the percentage distributions of the mesh and the bimodal and multimodal suspension mixtures.

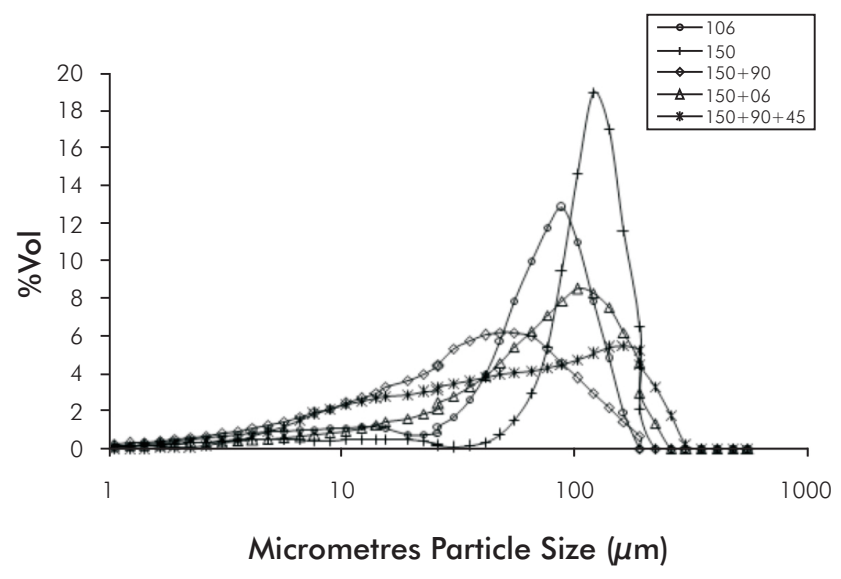

Figure 1. Distributions of particle size volumetric percentages, petroleum coke blends

Each suspension was tested for measurement of rheological behavior and static and dynamic stability. The static test consists of taking samples of the suspensions prepared and transporting them to graduated test tubes, where the percentage of free water in time is measured. The dynamic stability test consists of keeping the spread under the action of shearing in a rotational viscometer according to time, and determining the viscosity drop due to precipitation of solids.

Formulations with rheological parameters and optimal stability, that is, low viscosity with low creep efforts and high stability, were selected to conduct experiments on a pilot scale in a fluid dynamic simulation test (MCPFD). This measured flow parameters and determined power under extensive shutdown conditions and sudden pumping re-start.

\section{Equipment}

The conduction of the tests required the use of the following equipment.

a. Measurement of viscosity: Rheometer TA Instruments $1500 \mathrm{X}$ and Haake RS600.

b. Measurement of particle size and distribution: Master Sizer S. 
Table 1. Properties of analyzed samples

\begin{tabular}{|c|c|c|c|c|}
\hline \multirow{3}{*}{ Sample } & \multirow{3}{*}{$\begin{array}{l}\text { Specific } \\
\text { gravity }\end{array}$} & \multicolumn{3}{|c|}{ Particle size distribution } \\
\hline & & \multicolumn{3}{|c|}{$(\mu m)$} \\
\hline & & $d_{10}$ & $d_{50}$ & $\mathrm{~d}_{90}$ \\
\hline Petcoke & 1,25 & 22,1 & 161,7 & 459,0 \\
\hline Asphaltenes & 1,05 & 10,5 & 178,6 & 549,6 \\
\hline
\end{tabular}

Table 2. Particle size distribution by sieve

\begin{tabular}{|c|c|c|c|c|c|c|}
\hline Mesh & \multicolumn{3}{|c|}{ Particle size distribution: Petcoke } & \multicolumn{3}{|c|}{ Particle size distribution:Asphaltenes } \\
\hline \multirow{2}{*}{$\begin{array}{l}\text { U.S.A. Satndard Testing Sieve: } \\
\text { ASTM E-11 Specification }\end{array}$} & \multicolumn{3}{|c|}{$(\mu m)$} & \multicolumn{3}{|c|}{$(\mu m)$} \\
\hline & $d_{10}$ & $d_{50}$ & $\mathrm{~d}_{90}$ & $d_{10}$ & $d_{50}$ & $\mathrm{~d}_{90}$ \\
\hline 90 & 5,17 & 29,58 & 70,25 & 3,12 & 16,42 & 55,30 \\
\hline 106 & 7,37 & 51,47 & 108,56 & 5,61 & 31,23 & 75,4 \\
\hline 150 & 10,83 & 89,14 & 152,66 & 8,23 & 54,31 & 91,28 \\
\hline 180 & 67,19 & 148,03 & 217,6 & 10,21 & 97,3 & 138,23 \\
\hline 300 & 129,04 & 221,09 & 313,49 & 35,34 & 127,92 & 190,48 \\
\hline 420 & 228,96 & 341,04 & 408,61 & 55,29 & 150,34 & 340,45 \\
\hline
\end{tabular}

c. Grinding: Ball mill 15 inches in diameter and balls of $1 / 2,3 / 4$ and 1 inch in stainless steel.

d. USA Standard Testing Sieve, ASTM E-11 Specification.

e. System preparation and samples- mixtures of lowtorque, tanks.

f. Mini fluid dynamic test circuit (pilot scale).

The MCPFD consists of a closed circuit of $15 \mathrm{~m}$ of $3 / 4$ inch steel pipe, a magnetic flowmeter, Bourdon gauge, a section of transparent pipe, a DP helicoidal pump and a storage tank. The flow rate was changed from 0,2 to $2 \mathrm{~m} / \mathrm{s}$. and we determined the pressure drops in the mini circuit as well as the power in the engine through shutdown and restarting tests. See Figure 2.

\section{RESULTS AND DISCUSSION}

\section{Results of laboratory tests}

\section{Particle size selection}

To determine the minimum and maximum values of the particle diameters used when establishing the formulations, some suspensions with bimodal particle sizes were depicted. Also, we analyzed their effect on the rheological behavior.

Granulometric mixtures with $50 \%$ of solid loads were prepared, with the results being shown in Figure 3. These tests, together with the determination of static stability (Figure 4) concluded that suspensions formulated with mixtures, with particle diameters inferior to 100 microns, have viscosities greater than those required 


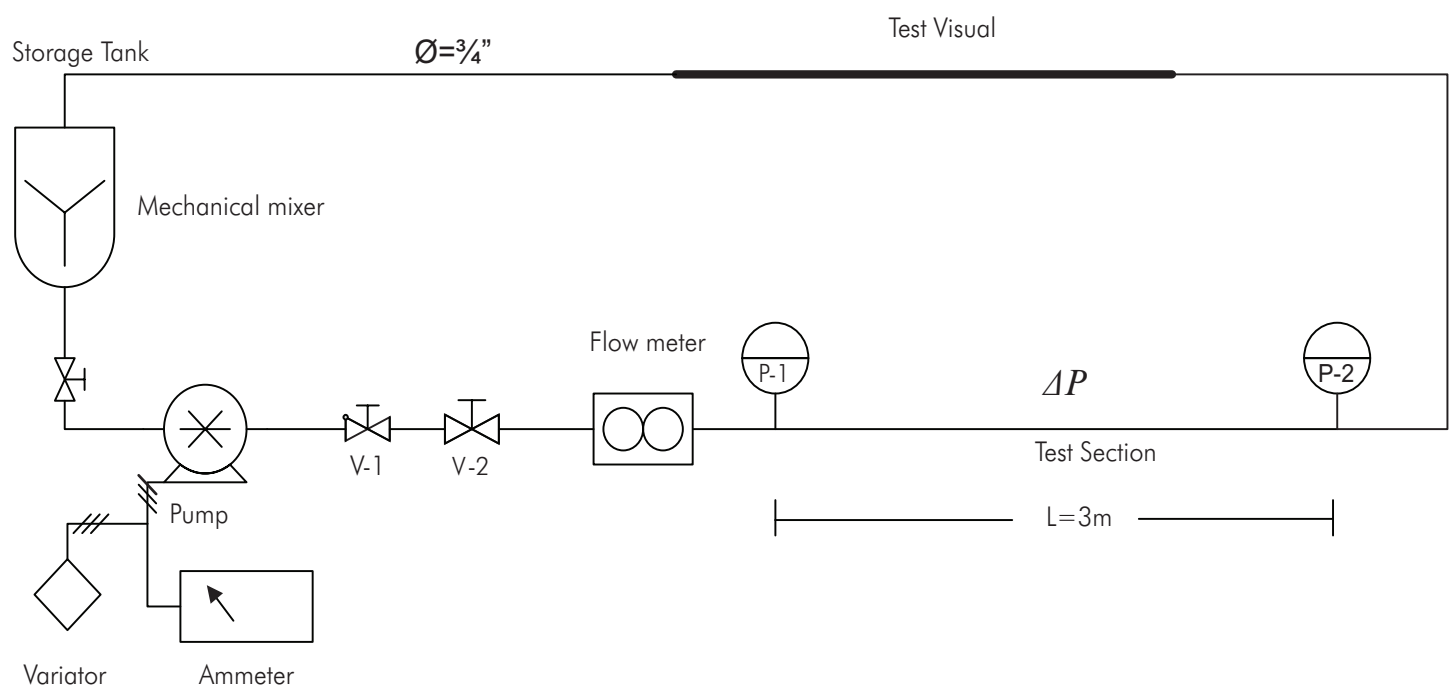

Figure 2. Schema: Pilot Plant Flow Mini Circuit Tests, Ecopetrol S.A. -ICP

for pipeline transport ( $400 \mathrm{cSt} 100 \mathrm{~s}^{-1}$ ). However, they are better in terms of stability. Contrary to this, suspensions with granulometric mixtures with diameters longer than 300 microns, have viscosities below $200 \mathrm{cP}$ at 100 $\left(\mathrm{s}^{-1}\right)$. These are less stable under static conditions, which mean a higher rate of precipitation of solids.

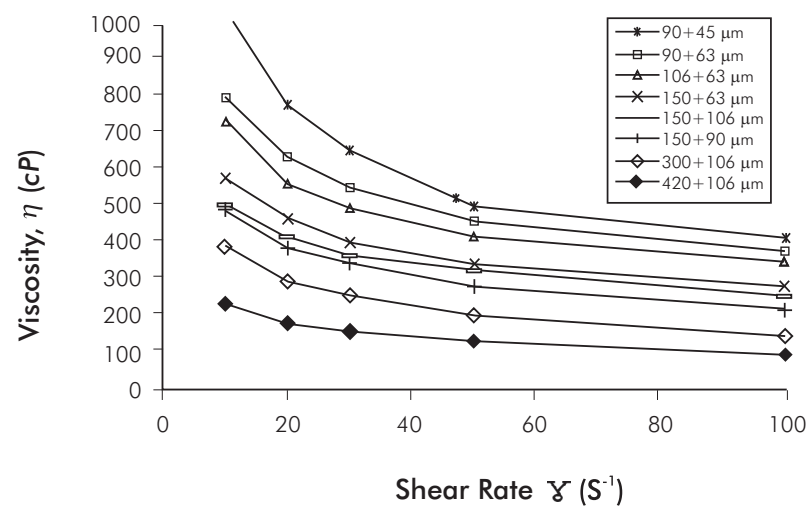

Figure 3. Rheological behavior of petroleum coke suspensions $(50 \% \mathrm{w} / \mathrm{w})$ in function of particle size

Finally, we took bimodal mixtures with a particle size ranging between $\mathrm{d}_{50}<90 \mu \mathrm{m}$ and $\mathrm{d}_{50}<150$ microns, which allowed us to obtain suspensions with viscosity below $300 \mathrm{cP}\left(25^{\circ} \mathrm{C}\right)$, as well as an improved stability. In regards to the samples described above, we want to stress the importance of minimizing the stratification of so- lids either for tank storage or pipeline transportation. Also, keeping high mobility and good flow behavior are necessary to ensure the integrity of the process.

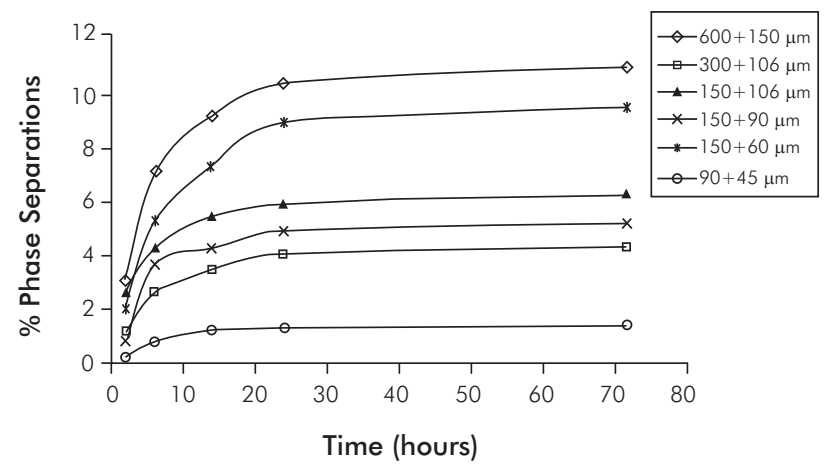

Figure 4 . Test of static stability of petroleum coke suspension $50 \% \mathrm{w} / \mathrm{w}$

After determining the particle size range of the bimodal mixtures, we prepared different combinations in different ratios, from thick Coarse to Fine particles to thin. We recorded ratios of solids from major to minor granulometry of $90 / 10,80 / 20,70 / 30,60 / 40$, and $50 / 50$.

Through rheological behavior tests, we found that bimodal formulations of 60/40 ratios allow a better load from solid to liquid with good mobility and stability. Figure 5 shows the results obtained. 


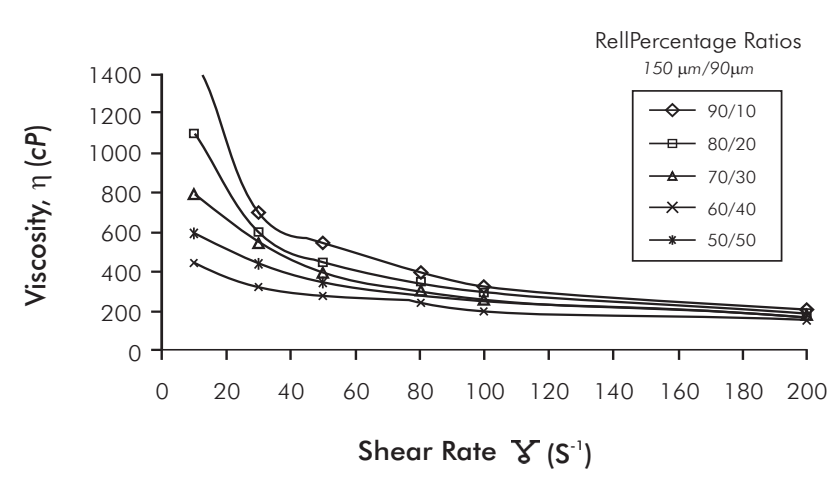

Figure 5. Rheological behavior of coke suspensions $50 \% \mathrm{w} / \mathrm{w}, 150 \mathrm{mi}-$ crons / $90 \mu \mathrm{m}$

\section{Solids concentration effect in the viscosity of petro- leum coke and asphaltenes suspensions}

Based on the combined distributions of particle sizes selected, coke / water and asphaltenes / and water suspensions with concentrations from $30 \%$ to $60 \% \mathrm{w} / \mathrm{w}$ solids were prepared. Rheology behavior measurements were made to determine the effect of the concentration of solids on viscosity. Results are shown in Figures 6 and 7.

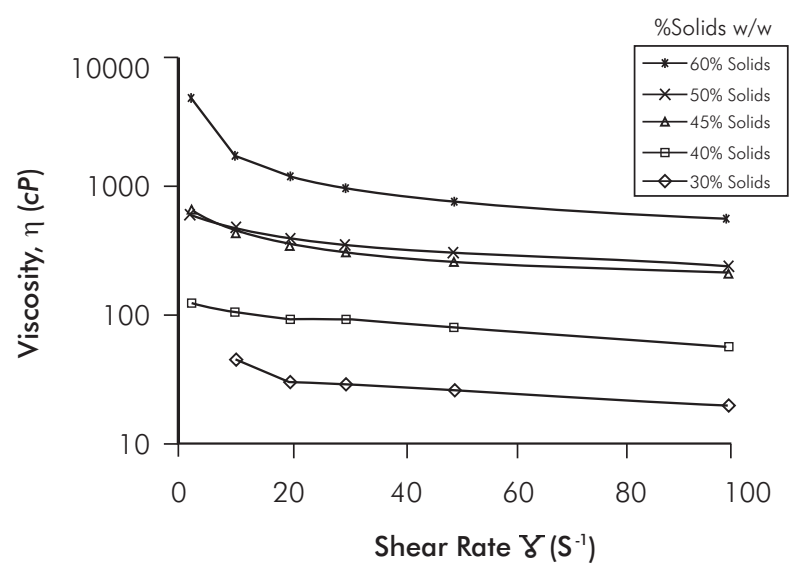

Figure 6. Effect of solids concentration on viscosity of petroleum cokewater suspensions

It can be observed that increase in viscosity is significant when solid concentration exceeds $50 \%$. As a result, formulations were adjusted to these conditions of solid to liquid loading in order to reach the viscosity threshold set as a reference for transport; that is, less than $400 \mathrm{cSt}$.

The dispersion raised its pseudoplastic character as the concentration of solids increased. Contrary to this, low concentration of solids maintained a flow pattern similar to a Newtonian fluid, and could be considered as a single phase flow.
The viscosity values of laboratory tests, taken as reference, were those measured at strain rates of $100 \mathrm{~s}^{-1}$. This is equivalent to deformations in pipelines bigger than 4-inches and with flow rates between 1 and $2 \mathrm{~m} / \mathrm{s}$.

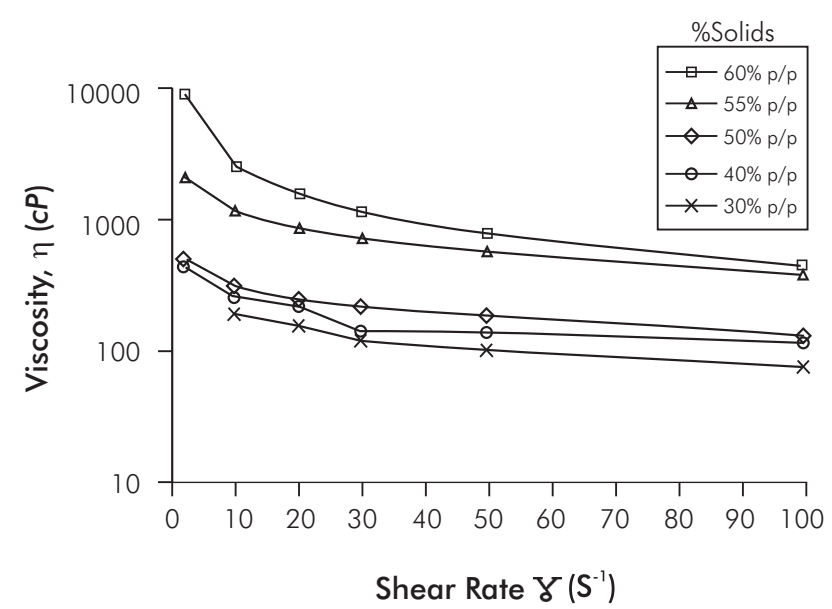

Figure 7. Effect of solids concentration on viscosity of asphaltenes water suspensions

\section{Selection of stabilizing additive}

Since both the terminal velocity and the critical velocity of deposit are directly related to the viscosity of the continuous phase, we used a thickener-stabilizing agent called AE, selected from a number of products tested at the laboratory. This agent showed the best increase in viscosity per unit of mass used. The products used and the results of the analysis are shown in Table 3.

The dosages applied and the rheological behavior of the formulated continuous phase used in the study (suspension formulation) are shown in Figure 8.

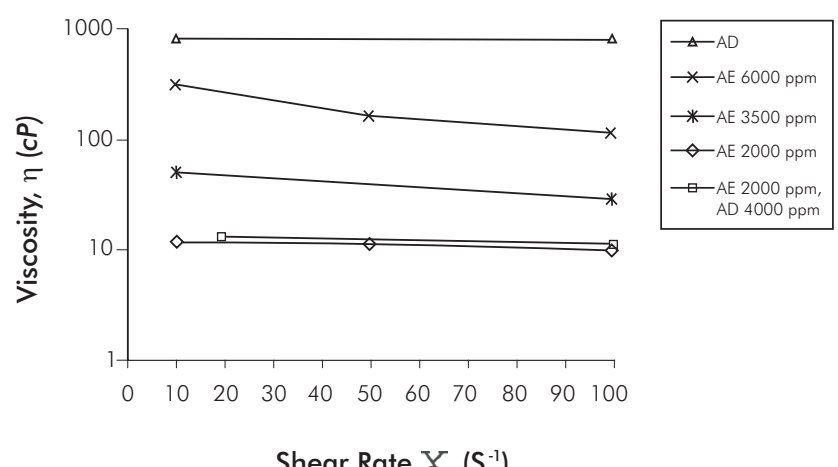

Figure 8. Rheological behavior of additive mixtures, as an effect of surfactant concentration on viscosity 
Table 3. Selection of stabilizing agent: Dynamic viscosity

\begin{tabular}{|l|cccc|}
\hline & \multicolumn{5}{c|}{ Thickening } \\
& Thickening agent & \multicolumn{4}{c|}{ Dinamic viscosity, $\mathrm{cP}\left(25^{\circ} \mathrm{C}\right)$} \\
\hline $\mathrm{AE}$ & $5000 \mathrm{ppm}$ & $7500 \mathrm{ppm}$ & $10000 \mathrm{ppm}$ & $15000 \mathrm{ppm}$ \\
\hline Galactasol & 87 & 235 & 395 & 780 \\
\hline Bermocol & 75 & 210 & 370 & 685 \\
\hline Carboxymethyl Cellulose & 33 & 113 & 252 & 461 \\
\hline Carboxyethyl Cellulose & 7 & 11 & 28 & 50 \\
\hline Celosize & 15 & 24 & 45 & 70 \\
\hline
\end{tabular}

The selected dosage of the thickener-stabilizing additive was the one which allowed a continuous phase with viscosity between 10 to $20 \mathrm{cP}$. As such, the idea was to keep the higher load of suspended solid particles, as well as viscosity lower than $400 \mathrm{cSt}$.

The continuous phase used in the formulation is composed of water with $\mathrm{AE}$ additives at a concentration of 2000 ppm and an AD dispersing agent at a concentration of $4000 \mathrm{ppm}$. This shows Newtonian behavior with viscosity in the range of 10 to $20 \mathrm{cP}$.

\section{Effects of dispersant agent's concentration in the visco- sity of petroleum coke and asphaltenes solid suspensions}

Once the granulometric selection and the viscosity of the continuous phase were defined, we performed optimization tests of the dispersing additive, through static and dynamic stability analysis. The dispersant used was selected from two commercial surfactants (Ethomid HP60, Ethomid HT23) and a product called in-House (AD).

The curve of critical micelle concentration (CMC) of the products are shown in Figure 9.

Following the static-stability tests (Figure 10) and $\mathrm{CMC}$, we selected the $\mathrm{AD}$ dispersant additive. At equal concentrations, we achieved minor 24-hour phases separation.

The next step in the process was the evaluation of rheological behavior in a mixture composed by $50 \%$ of solids, and $2000 \mathrm{ppm}$ of additive AE. This was done by changing $\mathrm{AD}$ concentration in a range between 2000 and 15000 ppm. Figure 11 shows the rheogram obtained.

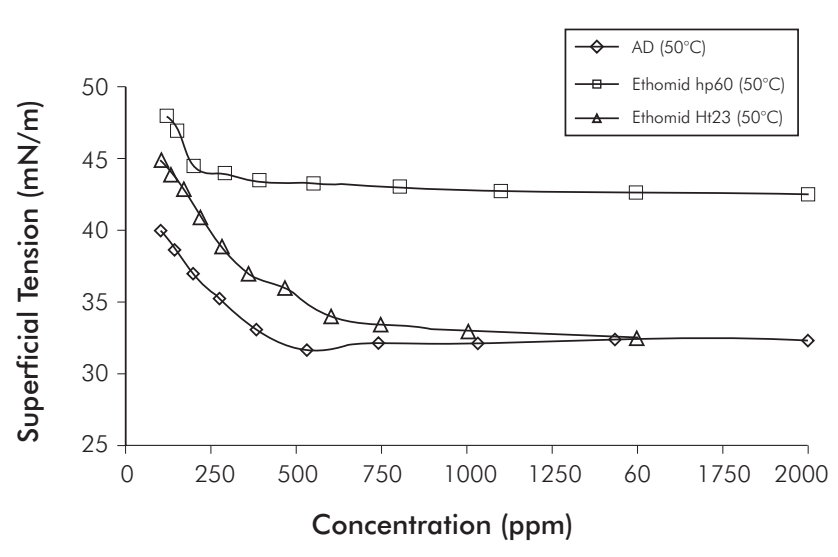

Figure 9. Critical micellar concentration of dispersants

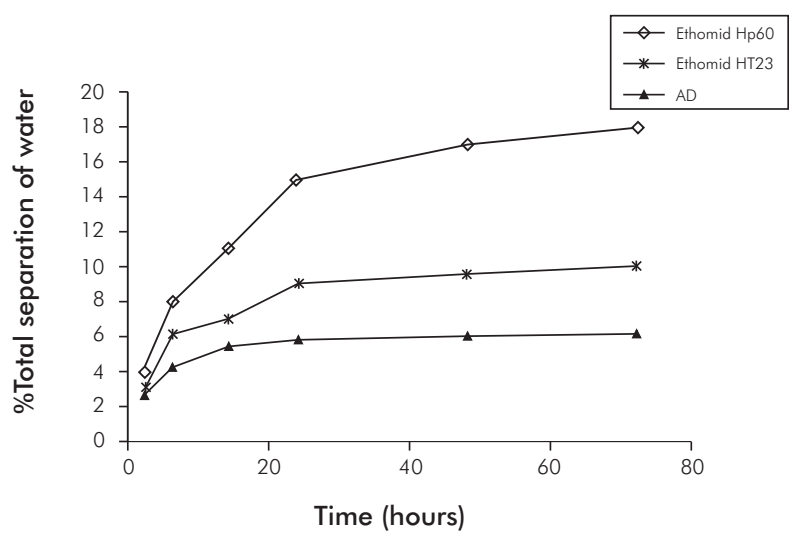

Figure 10. Solid Suspensions of Coke Petroleum w/w bimodal mixture $1150+90 \mu \mathrm{m}(60 / 40)$

After the corresponding analysis, the $4000 \mathrm{ppm}$ dose of $\mathrm{AD}$ additive was selected as the optimal formulation concentration. Lower concentrations promote an increase in viscosity due to a loss in lubricity of the continuous phase. Higher concentrations do not offer a 
considerable drop in viscosity or an increase in static or dynamic stability of the mixture to justify the addition.

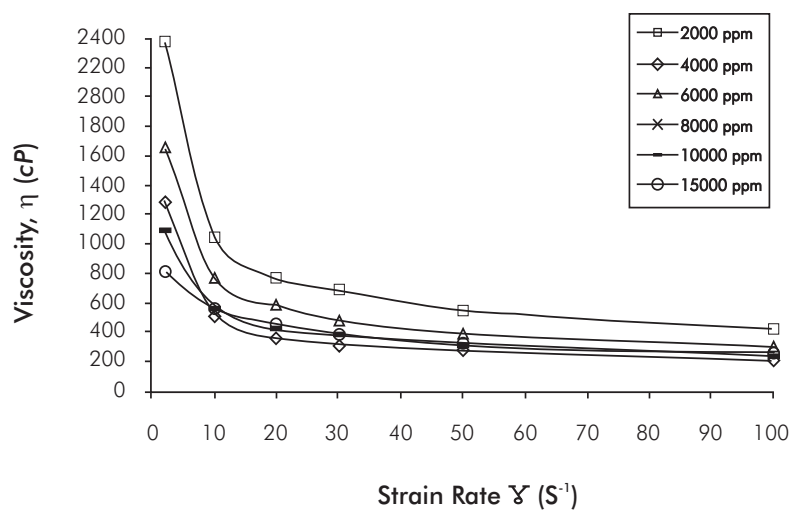

Figure 11. Effect of surfactant concentration on the viscosity of solid suspensions. Petroleum coke $50 \% \mathrm{w} / \mathrm{w}, 150 \mu \mathrm{m}+90$ microns $(60 / 40)$, 2000 ppm AE

Finally, the continuous formulated phase used in the preparation of suspensions correspond to water with a concentration of $2000 \mathrm{ppm}+/$ - 100 of AE stabilizing additive, and $4000 \mathrm{ppm}+/-200$ of dispersing additive.

\section{Hysteresis proof}

The Non-Newtonian time-dependent behavior (thixotropic reopectic) found in a variety of fluids, is often studied in terms of what is commonly called hysteresis curves, which result from subjecting a fluid to an increase in shear rate (and / or flow rate) for a given time. Following shear a rest, we lower the strain rate during a period equivalent to the initial one. These studies are useful to show how the fluid behaves during transport, which provides relevant information to indirectly establish stability and effects of rearrangement and orientation of particles suspended in a liquid, among others. When plotting the curves of viscosity under the increase of the shear rate-idle-reduction, we can determine whether hysteresis is present or not. If the resulting curves superimpose on one another, it can be said that the "fluid has memory."

For this case study, the thixotropy curves obtained show a viscosity decrease in the decline curve of the deformation rate (or flow). Particles -once the suspension is subjected to shear- rearrange themselves in such a way that they exert less internal friction between them, which results in lower viscosity. When pumping is restarted, after a possible shutdown, viscosity will be lower than when the pumping starts. This becomes a high convenience factor if we take into account the possibility of a critical case in which there is a shutdown during the pumping of the pipe suspension, and then the pumping restarts. The results obtained for one of the suspensions of asphaltenes and water, as defined by the above-mentioned formulation, are shown in Figures 12 and 13.

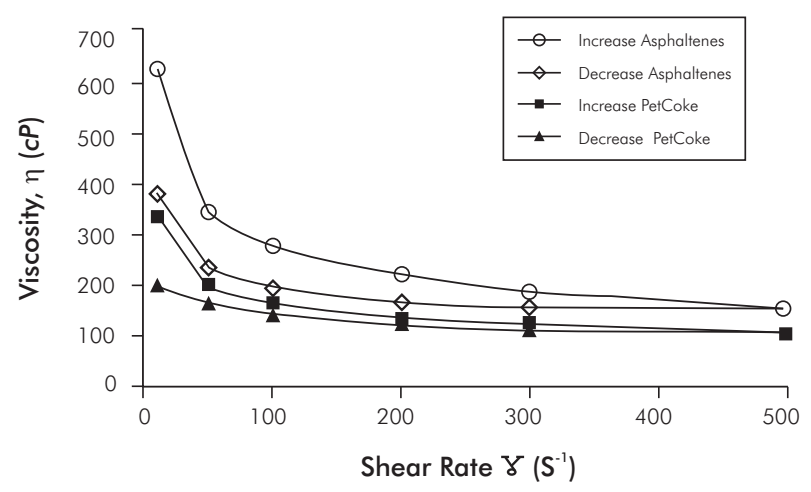

Figure 12. Hysteresis Curve ${ }^{*}: \eta$ vs $\gamma$

*Asphaltenes and petroleum coke water suspensions $50 / 50 \mathrm{w} / \mathrm{w}, 150 \mu \mathrm{m} / 90 \mu \mathrm{m}$ bimodal mixture (60/40) $[\eta]=$ Dynamic viscosity, $[Y]=$ Shear rate

Since the curve of increase is not overlapped by the curve of decline, we can conclude that the suspensions prepared from these formulations exhibit thixotropic behavior. Suspensions of petroleum coke showed the same behavior. The aforementioned characteristics are taken into account in the designs of operations and pipeline transport infrastructure, given that it is reflected on a decrease in shear stress or apparent viscosity when subjecting a fluid to a continuous deformation. This would represent a decrease in pumping power compared to a fluid with same viscosity and density but not thixotropic in nature.

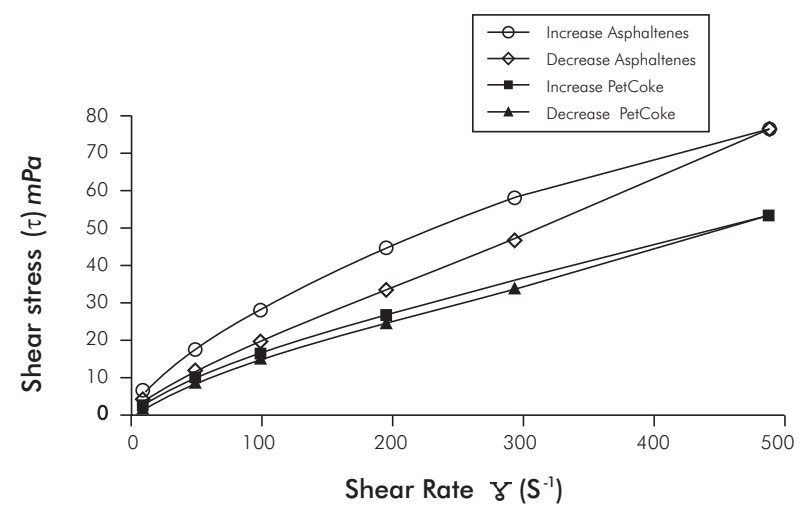

Figure 13. Hysteresis Curve*: $\tau$ vs צ

* Asphaltenes and petroleum coke water suspensions 50/50 w/w $150 \mu \mathrm{m} / 90 \mu \mathrm{m}$ bimodal mixture $(60 / 40)$ 


\section{Results of pilot plant mini circuit fluid dynamics MCPFD}

Prior to the tests of solid suspensions transport, we performed some tests by using water modified with $\mathrm{AE}$ additive, whose rheological characteristics were similar to a suspension of $300 \mathrm{cP}\left(20 \mathrm{~s}^{-1}\right)$ with a dosage of 6000 $\mathrm{ppm}$. This was done in order to calibrate the gauges and to ensure adaptation of the system to the flow conditions. The rheogram obtained for this mixture is shown in Figure 14.

The following results were obtained from tests conducted for scaling of suspension formulations at pilot plant level (MCPFD):

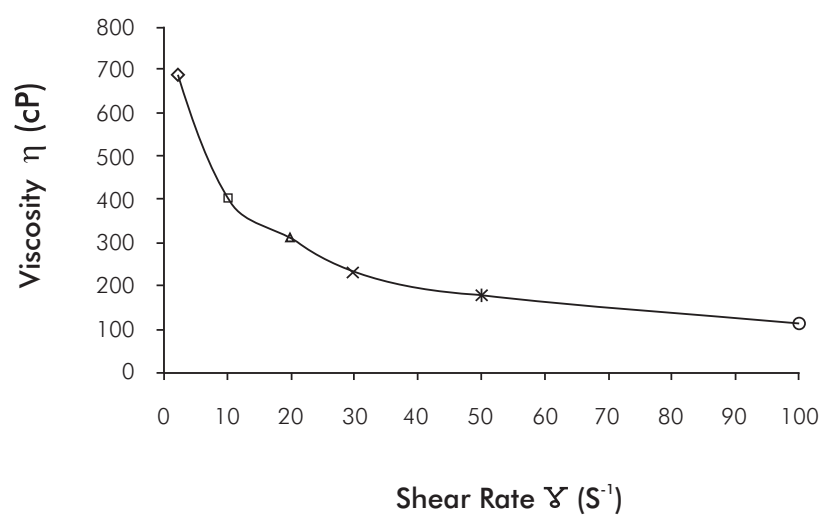

Figure 14. Rheogram of the AE-water mixture 6000 ppm

\section{Determination of pressure drop and calculation of viscosity from experimental data}

In order to reproduce or verify the dynamic fluid behavior of the formulation obtained in the laboratory, 10 gallons of water coke and asphaltenes water suspension were prepared and taken to the MCPFD. There, and from the formulation previously defined, we determined certain pressure drops of the suspensions prepared. The results obtained at pilot plant scale are shown in Figure 15.

It was observed that the pressure drops per length unit of coke suspensions were fewer compared to the suspensions of asphaltenes. This is directly related to the viscosity of each of these systems, which was corroborated with the results obtained at laboratory level. Since the suspensions formed by asphaltenes have a higher yield strength effort than those formed by petroleum coke, these exhibit greater pressure drop at the start of pumping. As a result, increases in the initial start-up power take place.

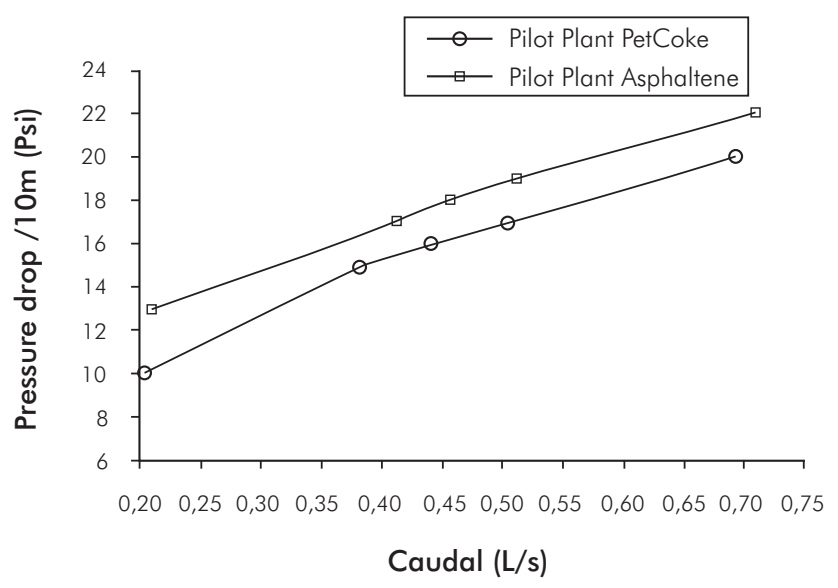

Figure 15. MCPFD pressure drops (coal and asphalt formulation)

Due to the physical and chemical structure of asphaltenes, it has been established that they are highly affected by attrition and / or breaking during transport, increasing its packed density as time goes by on the circuit.

From the equations describing steady-state, laminar flow, cirular piping and derivative similar to the Hagen Poiseuille equation for a power law type pseudoplastic fluid. (Govier \& Aziz, 1972), the apparent viscosity of the mixture, by means of experimental data, was calculated. These were compared with those made at the level of TA and Haake RS600 Rheometers of the PCI FIR laboratory, showing values within the range $+/-5 \%$. It was determined that the behavior of the suspension in the MCPFD is treated as a single phase fluid, and that correlations and equations for homogeneous flow will be used, without taking into account significant deviations in calculations. In all the tests conducted, the flow rate displayed was Laminar.

Due to the low volume of flow and a pipe diameter of $3 / 4$ "; a shear rate of $400 \mathrm{~s}^{-1}$ was estimated, being equivalent to the data found at rheometer level in laboratory, whose value of viscosity, at this shear rate, was $80 \mathrm{cP}$. 
Figure 16 shows the results obtained. It can be observed that viscosity values, corresponding to shear rates between $0-400 \mathrm{~s}^{-1}$ achieved at the laboratory, were superimposed by the values of apparent viscosity obtained with the data at pilot level. Due to flow conditions, the data showed good approximation.

These results show that the scale formulations maintain the pseudoplastic behavior established in the tests carried out at laboratory level. Thus, and owing to its non-Newtonian character, the viscosity of the suspension will depend on the flow rate and the diameter of the pipe being used.

\section{Shutdown and pumping re-start}

In order to determine the suspension stability under dynamic and static conditions, shutdown tests vs. pumping re-start with times of 1, 2, 3, 14, 24 and 72 hours were performed. The recirculation pattern was maintained. In all previous cases, the pumping restart was possible, and we noticed that increases in power were not significant for stop times inferior to 24 hours. As for shutdown times, higher than 24 hours, we observed a variation in power up to values close to $80 \%$, compared to the one obtained during a normal pumping operation of the completely homogenized mixture, as shown in Figure17.

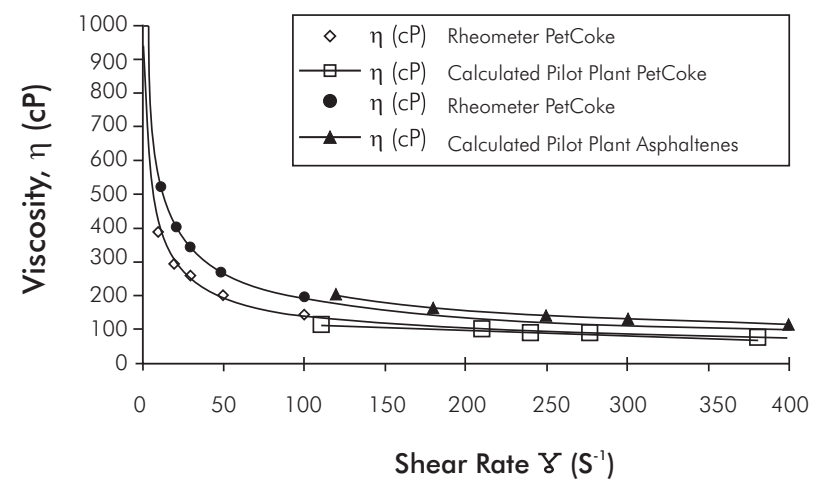

Figure 16. Apparent viscosity of coke coal suspensions compared to pilot plant and laboratory data

We performed a flow evaluation at $0,2 \mathrm{~m} / \mathrm{s}$ to determine if it was possible to reach the critical sedimentation conditions of the particulate matter in line with the ones of the test, under minimum speed. No change in pumping power was observed. In all cases, it was possible to successfully restart the system.

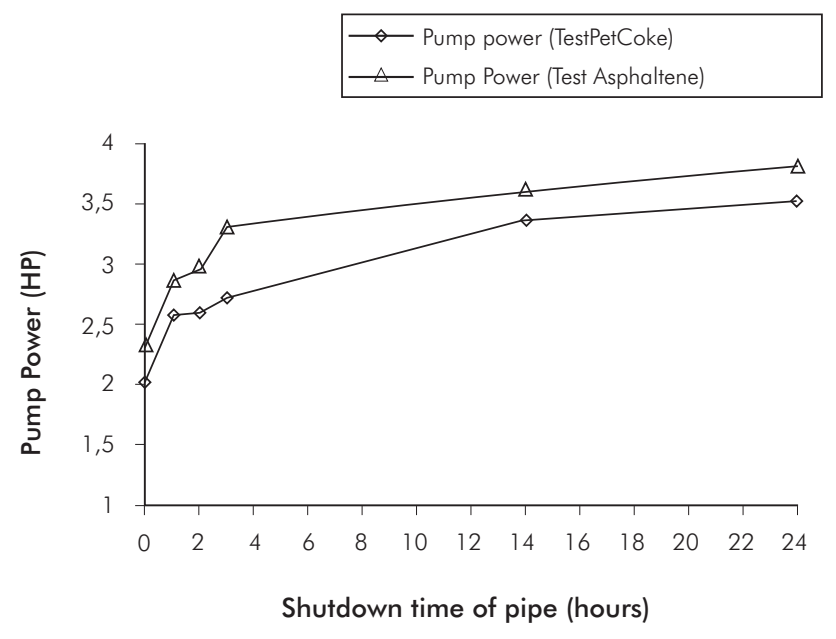

Figure 17. Increase in pump power in shutdown and re-start tests

\section{CONCLUSIONS}

- Due to the sensitivity observed in viscosity, with parameters such as solids concentration and particle size, the Rheological behavior studies of sub products suspensions in improvement processes allowed us to predict pressure drop, sizing and transmission lines of a pumping system in an optimized way. It was noted that an incorrect prediction of flow properties could lead to the design of a technically unfeasible plant.

- We found that the particle size for suspension transmission should be in the range of 90 to 150 microns. Values below this range increase the viscosity, and those above increase the precipitation of solids. When selecting a specific particle size, the design conditions of a plant should be considered, as well as the distance traveled (residence time), flow rate and use of suspension at the end of the tube. All of these depend on whether or not a possible dehydration process is needed.

- As for flow systems, in which the fluid maintains a maximum apparent viscosity below $400 \mathrm{cSt}$ at a given shear rate, the facilities required for handling (pumping stations, pipe diameter) are in the same order of magnitude to those commonly used in transportation of hydrocarbons and / or conventional fluid. 
- It was observed that if we needed to carry out a pumping shutdown or restart during a normal operation of transmission, it would be possible to obtain stable operating conditions. However, an increase in pumping power could be expected because the pseudo plastic character is stressed at low shear rates. This is something worth noticing when designing pumps for scaling processes.

- The concentrations that showed best rheological behavior and stability were 4000 ppm of agent (AD) and $2000 \mathrm{ppm}$ of stabilizer agent (AE). These values are equal to $0,6 \%$ of the overall composition of the mixture.

- It is possible to move byproducts suspensions of heavy oil upgraders through pipes, therefore achieving optimum viscosities for transportation with a solid concentration of $50 \% \pm 2 \%$.

\section{ACKNOWLEDGEMENTS}

The authors express their gratitude to engineer Gonzalo Leal Díaz, Ecopetrol's transport specialist, for his ongoing advice throughout the project. Also, to the staff working at ICP's Interfacial Phenomena and Rheology lab for their valuable, timely and effective assistance in conducting the analysis.

\section{REFERENCES}

Allen, J. W., Rennie, A. G. \& Welbourne, M. C. (1985). Atomization Coal Water Mixtures. International Chemical Engineering Symposium Series. 95: 101 - 113.

Ateşok, G., Dinçer, H., Ozer, M. \& Mütevellioğlu, A. (2005). The effects of dispersants (PSS-NSF) used in coal-water slurries on the grindability of coals of different structures. Fuel, 84: 801-808.

Boylu, F., Ateşok, G. \& Dinçer, H. (2005). The effect of carboxymethyl cellulose (CMC) on the stability of coal-water slurries. Fuel, 84: 315-319.
Boylu, F., Dinçer, H. \& Ateşok, G. (2004). Effect of coal particle size distribution, volume fraction and rank on the rheology of coal-water slurries. Fuel Processing Technology, 85: 241 - 250.

Chen, L., Duan, Y., Liu, M. \& Zhao, C. (2010). Slip Flow of coal water slurry in pipeline. Fuel, 89: 1119-1126.

Govier, G. W. \& Aziz, K. (1972). The Flow of complex mixtures in pipes. Van Nostrand Reinhold Company.

Grosso, J. L., Afanador, L. E., Guzmán, E. K., Parra, M., Barrero, R., Vidales, H., Rodríguez, L., Leal, G., Medina, O. J., Vergel, C. A. \& Arciniegas, R. (2003). Proceso de desasfaltado de hidrocarburos pesados con alto contenido de asfaltenos a condiciones bajas de presión y temperatura (DAO). Informe Técnico. Piedecuesta, Ecopetrol S.A. ICP.

Grosso, J. L., Suárez, M. \& Leal, G. (1996). Preparación transporte y combustión de hidrocarburos pesados y carbón pulverizado. Boletín CIT, 7 (6).

Hicyilmaz, C., Ozün, S. \& Altun, E. (2006). Rheological Properties of Asphaltite-Water Slurries. Energy \& Fuels, 20: 2037-2045.

Kefa, C., Guoquang, H. \& Mingjiang, N. (1985). Pipeline Conveyance and Fluidized Bed Combustion of Coal Water Mixture with High Viscosity: II. European Conference on Coal Liquid Mixtures, International Chemical Engineering Symposium Series, 95: 87 - 99.

Liu, J., Zhao, W., Zhou, J., Cheng, J. \& Zhang, G. (2009). An investigation on the rheological and sulfur-retention characteristics of desulfurizing coal water slurry with calcium-based additives. Full Processing Technology. 90 (2009), 91-98.

Murray, R. G., Elliott, J. W. \& McCaffrey, W. C. (2005). Asphaltene fluid properties at process conditions $J$. Petrol. Inst. 48 (4), 181-188.

Picón, H. J. \& Mahecha, C. A. (2001). Manual de Operación Planta Piloto de Coquización, Visco reducción y Pirolisis. División de Procesos no Catalíticos. Manual de Operación, Instituto Colombiano del Petróleo - (ICP) Ecopetrol S.A.

Wang, J., Anthony, E. \& Abanades, J. (2004). Clean and efficient use of petroleum coke for combustion and power generation. Fuel, 83: 1341-1248. 